\title{
Active Sympathetic Participation: Reconsidering Kant's Duty of Sympathy
}

\section{MELISSA SEYMOUR FAHMY \\ University of Georgia'}

In the Doctrine of Virtue Kant divides duties of love into three categories: beneficent activity (Wohltätigkeit), gratitude (Dankbarkeit) and Teilnehmung - commonly referred to as the duty of sympathy (MS 6: 452). ${ }^{2}$ In this paper I will argue that the content and scope of the third duty of love has been underestimated by both critics and defenders of Kant's ethical theory. The account which pervades the secondary literature maintains that the third duty of love includes only two components: an obligation to make use of our natural receptivity to sympathetic feelings as a means to fulfilling other duties of love, and an indirect duty to cultivate these feelings. ${ }^{3}$ As a result, Kant's duty of sympathy has been widely regarded as a duty whose value is derived from the way in which it serves other duties, in particular, the duty of beneficent activity, which obliges agents 'to promote according to one's means the happiness of others in need' (MS 6: 453). Teilnehmung has thus assumed something of a second-class status among the duties to others. My aim in this paper is to demonstrate that the prevailing account of Kant's third duty of love is incomplete. The fundamental obligation prescribed by the duty of Teilnehmung, I shall argue, is a direct duty of active sympathetic participation with others. A proper understanding of the nature and scope of this duty reveals that Kant's theory assigns a more significant role to the cultivation and expression of moral emotions than many have supposed. The view affirmed in the third duty of love is that we can and should take an active role in cultivating our emotional capacities, and not merely as a means to fulfilling other duties; rather, we are obliged to cultivate these capacities because they allow us to respond to persons with sensitivity and understanding. 
That the third duty of love has been underappreciated is not altogether surprising. In the first section of the paper, I examine some of the obstacles which stand in the way of an accurate assessment of the duty, one obstacle being the standard rendering of Teilnehmung as sympathy. In section two, I examine the first of two keys to understanding the duty of Teilnehmung, namely, the distinction Kant draws in $\$ 34$ of the Doctrine of Virtue between humanitas practica and humanitas aesthetica. In sections three and four, I explore a second key, the relationship between the direct and indirect obligations prescribed by this duty of love. Using these two keys I argue that the duty of Teilnehmung is best understood as a duty of active sympathetic participation. Because the nature of Kant's third duty of love is at issue, I will refer to the duty by the German term Teilnehmung until we have determined a suitable English rendering.

\section{Obstacles to Understanding Kant's Third Duty of Love}

In this section I would like to consider some of the obstacles to understanding Kant's third duty of love. Perhaps the best place to begin is with the title given to the section of the Doctrine of Virtue devoted to this duty - Teilnehmende Empfindung ist überhaupt Pflicht - which Mary Gregor translates as 'Sympathetic Feeling is Generally a Duty'. ${ }^{4}$ On the basis of the section title, one might be inclined to believe that Teilnehmung is simply the duty to have sympathetic feeling. A careful reading of the sections devoted to this duty of love ( $\$ 34$ and $\$ 35)$, however, reveals that this account is inaccurate. In the opening sentence of $\$ 35$ Kant writes:

But while it is not in itself a duty to have sympathetic sadness (Mitleid) (and so also sympathetic joy (Mitfreude)) with others, active Teilnehmung in their fate is; and to this end it is therefore an indirect duty to cultivate the compassionate natural (aesthetic) feelings in us, and to make use of them as so many means to Teilnehmung based on moral principles and the feelings appropriate to them. (MS 6: 457)

Here, Kant contrasts active Teilnehmung with the experience of feeling sympathetic sadness and joy (Mitleid and Mitfreude), claiming that while the former is a duty, the latter are not. This indicates that it would be erroneous to suppose that Teilnehmung is a duty simply 
to have sympathetic feelings. In her most recent translation, Gregor renders Teilnehmung as sympathy and to sympathize. ${ }^{6}$ While this translation is not literally incorrect, it obscures the distinction Kant makes in the passage quoted above. The term sympathy, I contend, is too similar to the phenomenon Kant claims is not a duty (Mitleid and Mitfreude) to be a precise or helpful rendering of Teilnehmung.

I indicated earlier that many of Kant's commentators associate the third duty of love with the indirect duty to cultivate sympathetic feelings. While Kant does state quite clearly that we have an indirect duty to cultivate our natural compassionate feelings, Teilnehmung cannot be identical with this cultivation, for Kant goes on to specify that we are to cultivate these feelings 'as so many means to Teilnehmung based on moral principles and the feeling appropriate to them' (MS 6: 457). ${ }^{7}$ In summary, the third duty of love is not a duty to have sympathetic feelings, nor is it exhausted by the indirect duty to cultivate these feelings. What then does the duty Kant designates as Teilnehmung prescribe?

Teilnehmung is difficult to translate, in part because Kant employs the term in a variety of different ways and in different contexts. ${ }^{8}$ The expectation that we can comprehend the nature of Kant's third duty of love simply by translating the word Teilnehmung may constitute an obstacle to an accurate account of the duty. If we wish to ascertain the nature of the third duty of love, it will be imperative to look beyond the appellation Kant gives to this duty and direct our attention to the context in which he presents it.

Before proceeding to an investigation of Kant's third duty of love, I would like to return briefly to the section title Teilnehmende Empfindung ist überhaupt Pflicht. I mentioned earlier that Gregor translates this as 'Sympathetic Feeling is Generally a Duty'. This rendering is likely inspired by the opening sentence of $\$ 34$, where Kant writes:

Sympathetic joy (Mitfreude) and sadness (Mitleid) (sympathia moralis) are sensible feelings of pleasure or displeasure (which are therefore to be called 'aesthetic') at another's state of joy or pain (shared feeling (Mitgefühl), sympathetic feeling (teilnehmende Empfindung)). (MS 6: 456)

Here Kant appears to consider teilnehmende Empfindung to be synonymous with Mitleid and Mitfreude. This presents a problem. If teilnehmende Empfindung is synonymous with Mitleid and 
Mitfreude, then the section title will be at odds with Kant's later claim that it is not a duty to have these sympathetic feelings. The inconsistency is avoided only if it can be demonstrated that teilnehmende Empfindung is somehow distinct from Mitleid and Mitfreude. I will explore this possibility in section four.

\section{Humanitas Practica}

One key to understanding the duty of Teilnehmung is found in the distinction Kant draws between humanitas practica and humanitas aesthetica. In the first paragraph of $\$ 34$, following an account of sympathetic feeling, Kant directs our attention to a facet of our common human nature, namely, that nature has implanted in us a receptivity (Empfänglichkeit) to share in the feelings of others. To make use of this receptivity, Kant tells us, is a duty of humanity, so named because 'the human being is regarded here not merely as a rational being but also as an animal endowed with reason' (MS 6: 456). Kant then draws the aforementioned distinction. (Though I quote Gregor's translation here, it should be noted that I do not fully endorse the translation, and will take issue with it shortly.)

Now, humanity can be located either in the capacity and the will to share in others' feelings (humanitas practica) or merely in the receptivity, given by nature itself, to the feelings of joy and sadness in common with others (bumanitas aesthetica). The first is free, and is therefore called sympathetic (communio sentiendi liberalis); it is based on practical reason. The second is unfree (communio sentiendi illiberalis, servilis); it can be called communicable (since it is like receptivity to warmth or contagious diseases), and also compassion, since it spreads naturally among human beings living near one another. There is obligation only to the first. (MS 6: 456-7)

Humanitas aesthetica is characterized by a purely natural receptivity or susceptibility to the feelings of joy and sadness with others. Such a receptivity to others' feelings, according to Kant's description, is passive and unwilled (unfree). Kant goes so far as to liken this sharing of feelings to the spread of a contagious disease, which is to say that it occurs irresistibly and independent of human willing. In so far as our receptivity is passive and unfree, there can be no obligation to it. Our obligation lies instead in humanitas practica. 
Humanitas practica, we are told, requires both capacity and will, but for what end? According to Gregor's translation (quoted above), humanitas practica is the 'capacity and will to share in others' feelings'. ${ }^{9}$ This translation, however, is flawed and distorts the nature of our obligation to others. The original German sentence reads as follows:

Diese [humanitas] kann nun in dem Vermögen und Willen, sich einander in Ansehung seiner Gefühle mitzuteilen (humanitas practica) ... gesetzt werden.

The first thing to note is the verb mitteilen. The principal meaning of mitteilen is to inform or communicate. Although the verb can also mean to share, the kind of sharing which can be denoted by mitteilen is an instance of giving to another that which is in one's possession, rather than sharing in something. ${ }^{10} \mathrm{Had}$ Kant intended to indicate sharing in, the verb teilnehmen would have been a better choice. ${ }^{11}$

A further problem with the translation is that it presents mitteilen as an act of sympathizing executed by an agent: the agent shares in others' feelings. This description, however, is not consistent with Kant's choice of pronouns. Kant uses the term einander, meaning each other or one another, suggesting that the action is reciprocal, rather than carried out by a single, principal agent. Furthermore, while Gregor's account presumes that the feelings Kant refers to belong to some indefinite others, the German pronominal adjective which modifies Gefüble is the singular seiner. Finally, Gregor's translation omits entirely the phrase 'in Ansehung' - in view of or with respect to - which helps to clarify the relationship between mitteilen and seiner Gefüble. The sentence should read as follows:

This [humanity] can be located in the capacity and will to communicate with each other in view of (with respect to) one's feelings (humanitas practica) ...12

The corrected translation, however, does not render the meaning of humanitas practica completely transparent, for Kant's description admits of some ambiguity. Just what are we obliged to communicate with one another? The phrase 'to communicate with each other in view of one's feelings' can be read in at least two ways. On the one hand, the phrase could indicate that we are to communicate our 
feelings directly with other persons, such that I make it known to another when I am experiencing sympathetic joy or sadness. On the other hand, if we emphasize 'in view of', the sentence could be read as indicating that we are to communicate with one another in a manner which is merely informed by our sympathetic feelings, such that one's communication is sensitive and empathetic rather than indifferent or detached. I will return to this ambiguity in section four when I address the relationship between the direct and indirect duties of Teilnehmung.

For now, it is enough to note that this rendering of humanitas practica (above) is considerably different from Gregor's sharing in others' feelings - an account which is conspicuously similar to humanitas aesthetica. The account of humanitas practica offered above is clearly distinct from humanitas aesthetica. This distinction is unambiguously important for Kant, and merits further attention before moving on.

Kant maintains that humanitas practica is free and is therefore called teilnehmend (see MS 6: 456-7 quoted above). In this context teilnehmend is intended to be descriptive of a kind of communication between persons, which is freely willed and concerns one's sympathetic feelings. The Latin phrase Kant includes, communio sentiendi liberalis - 'the free communion of sentiment' - expresses as much. ${ }^{13}$ Translating teilnehmend as sympathetic, which Gregor does, while again not literally incorrect, fails to capture the significance of the term as Kant employs it in this passage. The term sympathetic could equally well describe the involuntary sharing of emotion indicative of humanitas aesthetica. But Kant is clearly contrasting teilnehmend with communicable (mitteilend), the adjective he uses to describe bumanitas aesthetica. The fundamental quality that distinguishes humanitas practica from humanitas aesthetica is not that one is sympathetic whereas the other is not; but rather, that the former is deliberate, voluntarily willed, and based on practical reason and the latter is not. We must understand teilnehmend as intended to express as much, and the term 'sympathetic' does not do this. In light of this, I suggest that it is preferable to translate teilnehmend (at least in this instance) as participatory. This rendering is consistent with the preference of recent translators of Kant's work. ${ }^{14}$

The distinction Kant draws between humanitas practica and humanitas aesthetica is clearly a contrast between the active and the passive. Humanitas aesthetica is the experience of being affectively 
determined by stimuli in one's immediate environment, whereas humanitas practica employs the will and is grounded in practical reason. Kant maintains that we have an obligation only to the latter. We have seen that humanitas practica involves the free communication with one another with respect to one's feelings, but clearly more needs to be said about the nature of this obligation. Exploring Kant's claim that the direct duty of Teilnehmung is supported by an indirect duty to cultivate our sympathetic feelings will provide us with additional insight. I turn now to Kant's further description of the third duty of love.

\section{The Indirect Duty: Cultivating Natural Compassionate Feelings}

Kant explains the third duty of love in the following passage from the Doctrine of Virtue:

But while it is not in itself a duty to have sympathetic sadness (Mitleid) (and so also sympathetic joy (Mitfreude)) with others, active Teilnehmung in their fate is a duty; and to this end, it is therefore an indirect duty to cultivate the natural compassionate feelings in us, and make use of them as so many means to Teilnehmung based on moral principles and the feelings appropriate to them. - It is therefore a duty not to avoid the places where the poor who lack the most basic necessities are to be found but rather to seek them out, and not to shun sickrooms or debtors' prisons and so forth in order to avoid sharing painful feelings one may not be able to resist. (MS 6: 457)

I would like to consider more closely Kant's claim that we have 'an indirect duty to cultivate the natural compassionate feelings in us and to make use of them as so many means to Teilnehmung based on moral principles and the feelings appropriate to them' (emphasis mine). I argued earlier that the third duty of love cannot be reduced to this indirect duty to cultivate our feelings, for Kant claims that we are to use our cultivated feelings as a means to active Teilnehmung. According to this description, the direct duty of Teilnehmung is served by the indirect duty to cultivate our natural feelings. I believe that explicating the relationship between our direct and indirect obligations is a second key to understanding the third duty of love. We should begin by considering what cultivating our natural feelings means in this context. 
As we have seen, the duty to cultivate our compassionate feelings cannot be a duty to have or accumulate these feelings, given that we cannot generate feelings at will. Kant, unfortunately, does very little to explain what he intends by cultivate in the context of this duty of love. The following is, therefore, an attempt to articulate a plausible account of what cultivating our natural compassionate, or sympathetic, feelings might reasonably entail. My account of this cultivation includes more than what Kant himself offered on the subject; however, I take the account to be consistent with Kant's ethical theory and moral psychology.

In so far as the cultivation of our natural feelings is a duty, albeit an indirect one, it is natural to understand it as a kind of moral cultivation. Cultivating one's natural compassionate feelings would require that an agent arrive at a point where he or she can critically evaluate these feelings in accordance with moral principles. The first step of cultivation, then, is to become aware of our natural sympathetic responses. This will entail, on the one hand, that we resist the temptation to withdraw from uncomfortable situations in order to avoid sharing in others' sorrows. Kant suggests that we should go so far as to seek out the places where people are likely to be suffering - sickrooms and prisons. But we must also pay attention to the absence of sympathetic feelings. If we expose ourselves to the joy and suffering of others and find that we do not easily share in their feelings, we must ask why this is so. The moral cultivation of our natural sympathetic feelings requires us to recognize, and attempt to eradicate, impediments to our natural receptivity including resentment, envy, malice, and indifference..$^{15}$ The eradication or at least the suppression of these vices is a necessary first step in the cultivation of our feelings, and may be accomplished through practices of self-examination and self-reproach.

Once we are aware of our natural sympathetic responses we must develop the strength necessary to bring these feelings under reason's control. In his lectures on anthropology, Kant refers to this kind of strength as sensitivity, whereas sensitivity's opposite is denoted by the term sentimentality.

Sensitivity (Empfindsamkeit) is not opposed to equanimity. For it is a capacity (Vermögen) and a strength (Stärke) which either permits or prevents the state of pleasure as well as displeasure from entering the mind, and thus it possesses choice. On the other hand, sentimentality (Empfindelei) is a weakness by which we can be affected, even against our 
will, by sympathy for others' condition who, so to speak, can play at will on the organ of the sentimentalist. $(A 7: 236)^{16}$

The sensitive person, according to Kant's description, has the capacity to govern her affective state, at least to some significant extent. Kant maintains that the sensitive person is in a position to permit or prevent the state of pleasure as well as displeasure from entering the mind. This should probably be read as hyperbolic; with that in mind, let us try to make sense of Kant's claim. While the power to prevent certain states of the mind or feelings seems psychologically implausible for human beings, it is more plausible to think that the sensitive person has the power to decide whether to embrace a particular feeling or to resist it (though not necessarily the power to prevent or eradicate the feeling altogether). The sensitive person is thus in a position to exercise some control over her emotions. This is part and parcel of what Kant calls the duty of moral apathy, that is, the duty to bring all of our feeling and inclinations under reason's control (MS 6: 408-9). The sentimental person, on the other hand, is in no way the master of his affective state. He is easily overwhelmed by his sympathetic feelings, and consequently, easily manipulated by others. ${ }^{17}$

An agent who is aware of, and yet not overwhelmed by, her emotional responses to the joy and sorrow of others is in a position to evaluate her feelings on the basis of moral principles. This evaluation is essential to the moral cultivation of our feelings; for our natural receptivity to share in others' feelings is spontaneous and unreflective. As Kant explains in the Lectures on Ethics, feelings become moral feelings, which can be shared in a deliberate rather than a merely instinctual way, only after they have been subjected to reason:

feeling can be disclosed no otherwise, than by the imparting of thoughts; thus we must have an idea of the feeling in advance, and must hence have employed reason, in order to know it accurately before we share it, so that the feeling thereafter may be correct and not instinctual; without thoughts, therefore, we would have no feelings, at least none of the moral kind; the other would be able to evince, not moral, but only instinctual fellow-feeling (sympathy). (LE 27: 677, emphasis mine)

Sometimes our sympathetic feelings will be ones that we can approve of, such as when we feel sympathetic sadness with those who have 
suffered greatly in a natural disaster. But we might just as easily and unwittingly share in malicious, mean-spirited joy; a feeling that, upon reflection, we cannot approve. We must also be wary of those who may attempt (consciously or unconsciously) to manipulate us by exploiting our receptivity to others' feelings. A cunning lawyer may try to arouse our sympathy for a drunk driver. A self-pitying friend or acquaintance may seek validation by encouraging us to share her feelings and view her as an object of pity. Likewise, the passionate feelings of the indignant may arouse sympathetic feelings even before we consider whether the indignation is appropriate and justified. Cultivated feelings are feelings which have been subjected to some degree of moral scrutiny. It is on the basis of this moral evaluation that an agent must decide whether to embrace or resist a particular feeling. The indirect duty to cultivate one's natural compassionate feelings, thus, entails the following two components:

1 employing our natural receptivity to share in others' feelings by exposing ourselves to the joys and sorrows of others and by eradicating psychological impediments to this receptivity

2 endeavouring, to the best of our ability, to limit our sympathetic feelings to those we can morally endorse.

\section{Cultivating sensitivity}

Earlier we noted that Kant refers to the capacity to exercise control over one's responses to emotion as sensitivity. Sensitivity's merit, however, is not restricted to the agent's affective control. Kant goes on to suggest (in a regrettably sexist manner) that sensitivity, as a developed capacity, leads to better judgement.

Sensitivity is manly; for the man who wants to spare his wife and children tribulations or pain must possess so much fine feeling (feines Gefühl) as is necessary to judge their sensibility (Empfindung) not by his own strength, but rather by their weaknesses, and his delicacy of feeling (Empfindung) is essential to his generosity. $(A 7: 236)^{18}$

According to the description above, the sensitive person's fine feeling enables him to appreciate the others' feelings and their particular vulnerabilities, though he may not share them. This description of sensitivity is quite different from the one we noted earlier (though it is the sentence which immediately follows the previous quote). Sensitivity, in the first sense we considered, entails a power to choose 
to embrace or to reject a particular feeling. However, sensitivity, in this second sense, entails a significant cognitive achievement. The sensitive person does not simply share in others' feelings; he anticipates them. His cultivated sensitivity thereby improves his judgement with respect to his generosity (beneficence).

Is there any reason to think that the cultivation of our natural sympathetic feelings might also serve to enhance our sensitivity to the needs and vulnerabilities of others? There may be. Emotions play a role in how we remember. We are more likely to remember experiences that are accompanied by a strong emotional response than those that are not. Imagine witnessing someone being spoken to in a harsh, cold, and critical manner, perhaps by an employer or a spouse. As an observer, we share in the unpleasant experience, and, if we are emotionally tuned in, we will feel the sting of sympathetic pain as we register another's hurt and humiliation. Because the experience is a painful one, it is more likely to linger in our memory and inform our judgement in the future.

No doubt we could arrive at the same place by actually having the experience of being personally humiliated in this way. Nonetheless, what our sympathetic feelings provide us with is additional data about human vulnerabilities. It may be the case that I would not be particularly pained if someone criticized my cooking, but my receptivity to others' feelings alerts me to the fact that not everyone feels as I do. Cultivated sympathetic feelings allow us to draw on a repository of past emotional experiences and use this information to anticipate emotional responses, especially those that deviate from our own. It is therefore reasonable to think that agents will develop the capacity Kant calls sensitivity (in the second sense, i.e. the ability to imagine and anticipate the emotional responses of others) through the process of cultivating their compassionate feelings.

It is not clear whether Kant intended the development of sensitivity to be included in the scope of the indirect duty to cultivate our natural compassionate feelings. However, there is clearly reason to want to include sensitivity as part of any general account of moral development. Sensitivity may be an important supplement to sympathy, even cultivated sympathy, in so far as sensitivity allows us to respond appropriately to those who are prone to suppress or conceal their pain and sadness. ${ }^{19}$ Kant's comments in Anthropology (quoted above), as well as his warnings in the Doctrine of Virtue that the beneficent must be careful to avoid injuring the pride of one's 
beneficiary (MS 6: 448-9, 6: 453), indicate that he did appreciate how sensitivity enhances our interactions with others. In light of this, it is reasonable to consider the development of sensitivity to be a natural and desirable by-product of the cultivation prescribed by the indirect duty, whether or not the development of this capacity is itself prescribed.

\section{The Direct Duty: Active Sympathetic Participation}

Having articulated an account of the indirect duty to cultivate our natural compassionate feelings, we can now turn our attention to the direct duty Kant calls active Teilnehmung in the fate of others. Recall that Kant maintains that we are to make use of our cultivated feelings 'as so many means to Teilnehmung based on moral principles and the feelings appropriate to them' (MS 6: 457). Assuming that there is no conceptual distinction between the duty Kant calls active Teilnehmung and humanitas practica, the question before us is the following: in what way does the cultivation of our natural compassionate feelings serve as a means to fulfilling the obligation Kant describes as 'the capacity and will to communicate with each other in view of (with respect to) one's feelings'?

Cultivating our natural compassionate feelings would seem to provide us with those feelings that are appropriate, even morally good, to communicate with others. Our receptivity to others' feelings may draw us into the lives of others, but only in an involuntary and passive manner. When we elect to freely communicate our cultivated sympathetic feelings, however, we actively take an interest in their fate and demonstrate a thoughtful regard for their wellbeing. I noted earlier that Kant's description of humanitas practica is somewhat ambiguous. It could be read to mean that we are to communicate our feelings directly with other persons, or alternatively, that we are to communicate with one another in a manner which is merely informed by our sympathetic feelings. I fail to see any evidence in the text which would indicate a clear preference for one reading over the other; but I also fail to see any real need to choose between them. The cultivation of our natural compassionate feelings, as I have described in the previous section, would facilitate both the direct communication of these moral feelings, as well as communication which is thoughtfully informed by them. Recall that sensitivity to the feelings and vulnerabilities of others is thought 
to be at least a by-product of the cultivation indirectly prescribed by the third duty of love. What is key is that we make use of the products of this cultivation as a means to engaging with others in a manner which is responsive to their particular circumstances. In light of the discussion above, and in keeping with the preference of recent translators, I suggest that we render Teilnehmung as sympathetic participation. ${ }^{20}$ The direct duty prescribed by Kant's third duty of love is the duty of active sympathetic participation in the fate of others.

Active sympathetic participation consists in the expression of our cultivated sympathetic feelings through various forms of human communication. The point to be noted here is that it is not sufficient simply to have the appropriate feelings. The direct duty of sympathetic participation requires that these feelings be put into practice: we are to convey these feelings to those whose joy or sorrow we share and otherwise engage others with sensitivity and understanding. Verbal communication is perhaps the most direct and explicit, but other forms of communication may convey our sentiments equally well. When we mimic the facial expression of another, frowning or smiling, we indicate that we are sharing in his or her feelings. Some actions may also convey sympathetic feeling. If a friend suffers a death in the family we might elect to attend the funeral, even if we never met the departed. Our presence at the service is a demonstration of a shared sorrow for our friend's loss.

Active sympathetic participation entails putting ourselves in another's place, but it also entails directly engaging others. Kant's third duty of love necessitates resisting the temptation to isolate ourselves, either physically or emotionally, in order to take part in the lives of others. ${ }^{21}$ This entails not merely a passive sympathy with their plight, but rather an active attitude of concern, which expresses itself in open communication. This communication should acknowledge the particular circumstances of the other without compromising the respect to which the agent is entitled. The extent to which we sympathetically participate in another's life will vary significantly depending on the intimacy of the relationship. Kant identifies sympathetic participation as one of the key features of friendship considered in its ideal form (MS 6: 469). While we should not expect to share as intimately in the lives of our co-workers or neighbours as we do with our friends, we can certainly participate sympathetically in their situation to a lesser degree. The expression 
of sympathetic feelings is itself an expression of our regard for the other's well-being or happiness, and the moral law prescribes the happiness of all others as an end that is also a duty (MS 6: 385).

A final clue to understanding the third duty of love, the duty Kant calls the duty of humanity, is found in various accounts of the vice of Schadenfreude, which, Kant maintains, is the direct opposite of sympathetic participation (Teilnehmung) (MS 6: 459). Envy, ingratitude, and Schadenfreude, Kant explains,

are contrary to humanity; for just as the latter involves a participation in the person and state of the other, and is evinced in well-wishing, so these three vices involve a lack of participation, such that they evince an aversion, a dislike for the worth of the person, and for the other's merit and happiness, a contentment with his misfortune. Hence they also, and Schadenfreude especially, are directly opposed to moral sympathy and indicate inhumanity. (LE 27: 692)

As we have seen, our natural receptivity to share in the feelings of others gives rise to the duty to cultivate these feelings and make use of them for moral purposes. In addition to this receptivity, Kant notes that we also have a natural tendency to the exact opposite response, that is, a natural tendency to derive pleasure from the misfortune and suffering of another:

It is indeed natural that, by the laws of imagination (namely, the law of contrast), we feel our own well-being and even our good conduct more strongly when the misfortune of others or their downfall in scandal is put next to our own condition, as a foil to show it in so much the brighter light. (MS 6: 460)

The misfortune of others, as Kant notes, can make the quality of our own well-being resonate all the more strongly and thus become a source of pleasure. Schadenfreude - pleasure derived from another's misfortune - is the converse of Mitleid (natural sympathetic sadness). This is to say that Schadenfreude is an opposite reaction to the same phenomenon. However, both Schadenfreude and Mitleid are premoral, in so far as they are spontaneous, unmediated responses. Cultivated sympathetic sadness, therefore, has less in common with malevolent joy than Mitleid does. Kant thus identifies sympathetic participation (Teilnehmung), and not Mitleid, as the direct opposite of this vice. Expounding on this claim he writes: 
It is the haughtiness of others when their welfare is uninterrupted, and their self-conceit in their good conduct . . . that generate this malevolent joy, which is directly opposed to one's duty in accordance with the principle of sympathetic participation (Teilnehmung) (as expressed by Terence's honest Chremes): 'I am a human being; whatever befalls a human being concerns me too.' (MS 6: 460)

Here Kant asserts that the principle of sympathetic participation implies extending one's concern not just beyond one's own self-interest, but universally, to all persons. We find a similar interpretation of the quotation from Chremes in the Lectures on Ethics. Vigilantius notes:

Professor Kant explains the saying of Chremes, in Terence: homo nibil humani etc. to mean that I am a man, and everything that involves other men is also of interest to myself; I cannot limit my well-wishing to myself only, and must show it to be active in regard to every other. (LE 27: 677)

Nature supplies us with a receptivity to share in others' feelings, as well as a sympathetic imagination (MS 6: 456, $A$ 179), but only through deliberate, conscientious cultivation can we employ these natural gifts for a moral purpose, a purpose which Kant calls the duty of humanity (MS 6: 456). 'To be humane', he contends, 'is to interest oneself in the fate of other men; inhumanity is to take no interest in what happens to them' (LE 27: 419). We are obliged by the duty of humanity to take an interest in the fate of others and to show it to be active by freely communicating our thoughts and feelings.

Kant suggests that human beings, though they are destined to live in societies, are not naturally sociable creatures (IAG 44-45, MS 6: 471, and A 7: 322). In Anthropology from a Pragmatic Point of View, Kant picks out communication as the defining feature of persons in a social condition, but claims that this condition is sociable only when individuals also participate in the pleasures (and presumably the pains) of others (A 7: 240). In a similar vein, Kant writes in the Critique of Judgement that when the two aspects of humanity - universal shared feelings (Teilnehmungsgefühl) and the capacity to communicate universally and most sincerely - are combined they 'constitute the sociability that is appropriate to humankind, by means of which it distinguishes itself from the limitation of animals' (KU 5: 355). The duty of sympathetic participation thus 
turns out to reflect one of the ways in which Kant's moral theory is informed by his understanding of human nature, a connection that was for some time neglected, but, thanks in particular to Allen Wood's work, is now receiving its due. ${ }^{22}$ The duty of sympathetic participation directs us to employ our natural receptivity to share in others' feelings in the service of cultivating sociable conditions which are conducive to the further development of human culture and morality.

At this point we can return to the postponed discussion of the section title: 'Sympathetic Feeling as Such Is a Duty' (Teilnehmende Empfindung ist überhaupt Pflicht). If we understand teilnehmende Empfindung to designate cultivated sympathetic feeling, then we can distinguish this feeling from the uncultivated sympathetic joy and sadness which arise spontaneously from our natural receptivity to share in others' feelings. This would render the title consistent with Kant's later claim that there is no duty to have sympathetic joy (Mitfreude) and sadness (Mitleid) (MS 6: 457). ${ }^{23}$

\section{Cultivated feelings and beneficence}

Many of Kant's recent commentators maintain that we are obliged to cultivate our sympathetic feelings as a means to successful compliance with the duty of beneficent activity. ${ }^{24}$ As I mentioned earlier, it is certainly Kant's view that our beneficent conduct should be sensitive to the vulnerabilities of others. He claims, for instance, that in helping someone poor 'it is our duty to behave as if our help is either merely what is due him or but a slight service of love, and to spare him humiliation and maintain his respect for himself' (MS 6: 449). This is an important point to make about the duty of beneficent activity: we are more likely to benefit another if we are sensitive and sympathetic to his particular situation. It is therefore quite reasonable to suppose that complying with the duty of sympathetic participation will improve our ability to comply with the duty of beneficence, which obliges us to promote the happiness of others as they understand it (MS 6: 453-4).

But to acknowledge only this contribution to beneficent conduct is to greatly underestimate the scope of Kant's third duty of love. There is no reason to think that our cultivated feelings and sensitivity should inform only our beneficent conduct. All of our interactions with others are enriched by an appreciation of their feelings, needs, and vulnerabilities. And unlike beneficence, 
sympathetic participation with others is not limited by our resources (money, time, skill, etc.) but can, at least in principle, be extended to many persons with whom we have contact. Another dissimilarity between the duty of beneficent activity and the duty of sympathetic participation is worth noting here. The former duty can be executed in secrecy, such that the benefactor remains unknown to the one he or she has benefited. Kant, in fact, suggests that this form of beneficence may be preferable in so far as it spares the recipient from feelings of humility which are potentially damaging to his self-esteem (MS 6: 453). The duty of sympathetic participation, however, cannot be executed anonymously; it is fundamentally a duty to resist the temptation to isolate ourselves from others and engage them actively and affectively.

\section{Conclusion}

A proper understanding of the nature and scope of the third duty of love - the duty of active sympathetic participation - reveals that Kant's ethical theory recognizes that cultivated emotions enhance our interactions with others in precisely those ways that critics like David Cartwright claim it does not. According to Cartwright:

the Kantian assessment of the moral importance of these feelings [love, compassion, sympathy, and gratitude] does not appreciate how they reveal a unity and connectiveness of being, something recognized by a number of theorists. These kind-hearted emotions wean individuals away from immature expressions of egoism into a wider participation with one's fellows ... The communication of feeling brings home the reality and the situation of another in ways reserved ordinarily only for one's own good or evil. Not only is there a morally appropriate response to another's good or evil involved in these feelings, the conative functions of these emotions serve to begin to put on par our separate ends as they incline me to pursue your ends as I pursue mine. They unite us by and in our sentient nature and our capacities to enjoy and suffer. While these feelings are not sufficient to account for all facets of morality and our moral lives, they have a vital role in morality and this is missed by Kant. (1987: 298-9)

As I have described it, the duty of active sympathetic participation directs us (a) to employ our natural receptivity to share in the feelings of others to produce cultivated sympathetic feelings, (b) to express our cultivated emotions through various forms of communication, 
and (c) to make use of the sensitivity which is a product of the cultivation of our natural compassionate feelings in our interactions with others. Kant's ethical theory must, to this extent, be credited with recognizing the moral significance of shared sentiment. But Kant's theory, in fact, recognizes more than this: what Kant identifies in the third duty of love is a moral responsibility to develop - intentionally and thoughtfully - our natural receptivity to share in others' feelings, and to make use of this gift as a means to actively and affectively participating in the fate of other persons. This participation, primarily responsive rather than beneficent, draws us closer to one another and is one of the means by which we transcend our own self-interest and form moral communities in the richest sense of the term.

\section{Notes}

1 I would like to thank Marcia Baron, Allen Wood, Jens Timmerman, Lara Denis, Anne Margaret Baxley, Paul D. Eisenberg, Dan Farnham, René Jagnow, Sarah Wright and anonymous referees for the Kantian Review for their comments on an earlier version of this article.

2 Citations in the text refer to the following English translations unless otherwise noted. All volume and page numbers refer to the Prussian Academy edition of Kant's Gesammelte Schriften:

MS The Metaphysics of Morals, trans. Mary Gregor (Cambridge: Cambridge UP), 1996.

G Groundwork of the Metaphysics of Morals, trans. Mary Gregor (Cambridge: Cambridge UP), 1997.

KpV Critique of Practical Reason, trans. Mary Gregor (Cambridge: Cambridge UP), 1997.

KU Critique of the Power of Judgment, trans. Paul Guyer (Cambridge: Cambridge UP), 2000.

SF The Conflict of the Faculties, trans. Mary Gregor (New York: Abaris Books), 1979.

A Anthropology from a Pragmatic Point of View, trans. Robert B. Louden (Cambridge: Cambridge UP), 2006.

LE Lectures on Ethics, trans. Peter Heath (Cambridge: Cambridge UP), 1997.

$P \quad$ Education, trans. Annette Churton (Ann Arbor: University of Michigan Press), 1960.

IAG 'Idea for a Universal History with a Cosmopolitan Purpose', trans. H. B. Nisbet. In H. S. Reiss (ed.), Kant: Political Writings (Cambridge: Cambridge UP), 2003. 
Gregor translates Der Pflicht der Wohltätigkeit as 'duty of beneficence'. I prefer duty of beneficent activity in so far as this distinguishes the particular duty of love - 'to promote according to one's means the happiness of others in need' (MS 6: 453) - from what Kant calls the maxim or duty of beneficence (Wohltun) - 'making others' happiness one's end, and the duty to it consists in the subject's being constrained by his reason to adopt this maxim as a universal law' (MS 6: 452).

3 See Gregor (1963: 197-9), Allison (1990: 166-7), Guyer (1993: 3889), Baron (1995: chapter 6), Sherman (1997: 142-6), Denis (2000: 48-73) and Stohr (2002: 187-204).

4 Jens Timmerman has suggested to me in correspondence that a more appropriate translation of überhaupt is 'as such', rather than 'generally'.

5 I have deviated here from Gregor's translation in order to draw attention to Kant's use of the terms Mitleid and Mitfreude. Gregor's translation reads as follows: 'But while it is not in itself a duty to share in the suffering (as well as the joys) of others, it is a duty to sympathize actively in their fate; and to this end it is therefore an indirect duty to cultivate the compassionate natural (aesthetic) feelings in us, and make use of them as so many means to sympathy based on moral principles and the feelings appropriate to them'.

6 Notably, in an earlier translation of the Tugendlehre, Gregor translates Teilnehmung as 'to participate' and 'participating'. See (Kant 1964). In the following sections of the paper I will explain why I find this translation to be preferable.

7 The German reads: 'und zu dem Ende also indirekte Pflicht, die mitleidige natürliche (ästhetische) Gefühle in uns zu kultivieren, und sie, als so viele Mittel zur Teilnehmung aus moralischen Grundsätzen und dem ihnen gemäßen Gefühl zu benutzen'.

8 See G 4: 423, MS 6: 459, A 7: 236, SF 7: 85 and P 9: 487.

9 James W. Ellington offers a nearly identical rendering in his 1983 translation of the Tugendlehre. According to Ellington's translation humanitas practica is 'the capacity and will to share another's feelings'. See Kant (1983).

10 Duden: das grosse Wörterbuch der deutschen Sprache in sechs Bänden. See also: The Oxford-Duden German Dictionary, Collins GermanEnglish English-German Dictionary, Langenscheidt Standard German Dictionary, Cassell's German-English English-German Dictionary.

11 Gregor's renderings of mitteilen in other contexts are consistent with the account I have presented. Gregor frequently, though not always, elects to translate mitteilen with some form of the verb communicate. See KpV 5: 58 and 5: 160, MS 6: 238, CF 7: 104, and Kant (1974) 7: 219, 7: 240, and 7: 313. When she does elect to translate mitteilen with 'share', this generally indicates either a form of communication or a giving of something to another. For instance, in Anthropology Gregor translates 'die Neuigkeiten des Tages mitzuteilen' as 'share the news of the day' (Kant 1974, 7: 317), and in the Doctrine of Virtue, she translates mitteilen as 'share' when the sharing in question refers 
to the secrets of a friend (MS 6: 472) and the distribution of 'all the happiness possible in the world' hypothetically imagined to be in one's exclusive possession (MS 6: 480).

12 I wish to thank Sabine Demetz and Fritz Breithaupt for their help with this translation.

13 I wish to thank Paul Spade for his help with the translation. The term 'communion' here, I believe, signifies a very intimate sharing and communicating with regard to one another's feelings.

14 See Kant (2002: 40, 2000: 229, 1997: 421). Notably, in her 1964 translation of the Tugendlehre, Gregor renders teilnehmend as 'partaking' rather than 'sympathetic'. In what follows I treat the terms 'compassionate' (Gregor's rendering of mitleidige) and 'sympathetic' as more or less synonymous.

15 See LE 27: 696.

16 The translation is Louden's; however, I have substituted 'capacity' for Vermögen and 'strength' for Stärke where Louden uses 'faculty' and 'power' respectively.

17 The section of the Doctrine of Virtue devoted to the explication of the third duty of love contains a rather striking passage where Kant appears to praise the rejection of compassionate feelings. Kant writes, 'It was a sublime way of thinking that the Stoic ascribed to his wise man when he had him say "I wish for a friend, not that he might help $m e$ in poverty, sickness, and imprisonment, etc., but rather that I might stand by him and rescue a human being." But the same wise man, when he could not rescue his friend, said to himself "what is it to me?" In other words, he rejected compassion' (MS 6: 457). I concur with the interpretation offered by Marcia Baron (1995: 212-7) and Lara Denis (2000) that what Kant is praising in this passage is not the absence of emotion, but rather the wise man's rational self-control.

18 The translation is my own.

19 I thank Dan Farnham for bringing this point to my attention.

20 See Kant (2002: 40, 1997: 421) and Wood (2008: 176-78).

21 In an appendix to the Doctrine of the Elements of Ethics Kant writes, 'It is a duty to oneself as well as others not to isolate oneself (separatistam agere), but rather to use one's moral perfection in social intercourse (officium commercii, sociabilitas)' (MS 6: 473).

22 Wood (1991: 325-351) and (1999: chapter 9).

23 I think we should still find the title somewhat odd, given that strictly speaking it is the cultivation and the expression of our sympathetic feelings which are duties, rather than the feelings themselves.

24 See Gregor (1963: 197), Allison (1990: 166), Guyer (1993: 388-9), Baron (1995: 220), Sherman (1997: 142), and Denis (2000: 50). In the previous section Kant writes that to use our natural receptivity to shared feelings 'as a means to promoting active and rational benevolence is still a particular, though only a conditional duty' (MS 6: 456). This might invite the view that we are to cultivate our sympathetic feelings as a means to successful compliance with the duty of beneficent activity, but it is not clear that this is what the sentence means. This 
is because it is unclear what Kant means here by active and rational benevolence (des tätigen und vernünftigen Wohlwollen). 'Benevolence' (Woblwollen) is not a term that Kant uses to denote the promotion of others' happiness. Rather, Kant employs the terms Wohltun and Wohltätigkeit to pick out this duty. In one place Kant implies that active, practical benevolence is equivalent to beneficence (Wohltun), but in this instance the word 'beneficence' means making the wellbeing and happiness of others my end rather than the promotion of others' happiness (MS 6: 452). In so far as there is reason to think that promotion of an end and embracing an end as one's own are not equivalent (see MS 6: 381), we should not assume that 'des tätigen und vernünftigen Wohlwollen' is identical to Wohltätigkeit. This issue is beyond the scope of the present paper. Even if Kant's reference to 'active and rational benevolence' is indeed a reference to beneficent action, this will not explain what Kant means when he says that we should cultivate our natural compassionate feelings 'as so many means to sympathetic participation (Teilnehmung) based on moral principles and the feelings appropriate to them' (MS 6: 457).

\section{References}

Allison, Henry (1990) Kant's Theory of Freedom (Cambridge: Cambridge University Press).

Baron, Marcia (1995) Kantian Ethics Almost without Apology (Ithaca, NY: Cornell University Press).

Cartwright, David (1987) 'Kant's view of the moral significance of kindhearted emotions and the moral insignificance of Kant's view', The Journal of Value Inquiry, 21: 298-9.

Cassell's German-English English-German Dictionary (1978) (New York: Macmillan Publishing Company).

Collins German-English English-German Dictionary, 5th edition (2004), ed. Peter Terrell, Veronika Schnorr, Wendy V. A. Smith and Roland Breitsprecher (London, New York: Collins).

Denis, Lara (2000) 'Kant's cold sage and the sublimity of apathy', Kantian Review, 4: 48-73.

Duden: das grosse Wörterbuch der deutschen Sprache in sechs Bänden (CD-ROM) (2000) (Mannheim: Dudenverlag).

Gregor, Mary (1963) Laws of Freedom (New York: Barnes \& Noble).

Guyer, Paul (1993) Kant and the Experience of Freedom (Cambridge: Cambridge University Press).

Kant, Immanuel (1964) The Doctrine of Virtue, trans. Mary Gregor (Philadelphia: University of Pennsylvania Press).

- (1983) Kant's Ethical Philosophy, trans. James W. Ellington (Indianapolis, IN: Hacket).

- (1974) Anthropology from a Pragmatic Point of View, trans. Mary Gregor (The Hague: Nijhoff). 
—. (1997) Lectures on Ethics, trans. Peter Heath (Cambridge: Cambridge University Press).

- (2000) Critique of the Power of Judgment, trans. Paul Guyer (Cambridge: Cambridge University Press).

- (2002) Groundwork of the Metaphysics of Morals, trans. Allen Wood (New Haven, CT: Yale University Press).

Langenscheidt Standard German Dictionary (1993), ed. Heinz Messinger, Gisela Türck and Helmut Willmann (Berlin, Munich: Langenscheidt).

The Oxford-Duden German Dictionary, revised edition (1997), ed. W. Scholze-Stubenrecht and J. B. Sykes (Oxford: Clarendon Press).

Sherman, Nancy (1997) Making a Necessity of Virtue: Aristotle and Kant on Virtue (Cambridge: Cambridge University Press).

Stohr, Karen (2002) 'Virtue ethics and Kant's cold-hearted benefactor', Journal of Value Inquiry, 36: 187-204.

Wood, Allen (1990) Kant's Ethical Thought (Cambridge: Cambridge University Press).

- (1991) 'Unsociable sociability: the anthropological basis of Kantian ethics. Philosophical Topics', 19: 325-51.

—. (2008) Kantian Ethics (Cambridge: Cambridge University Press). 